
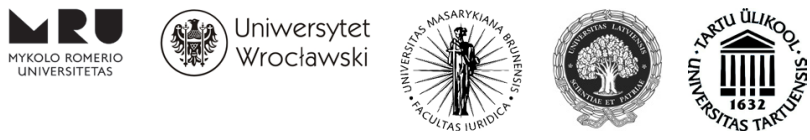

ISSN 1392-6195 (print) ISSN 2029-2058 (online) JURISPRUDENCIJA JURISPRUDENCE 2014, 21(4), p. 1208-1232.

\title{
DECENTRALIZATION IN ROMANIA: A CONSTANT FAILED REFORM UNDER SCRUTINY FROM THE CONSTITUTIONAL LIMITS PERSPECTIVE
}

\author{
Radu Carp \\ University of Bucharest, Faculty of Political Science \\ Spiru Haret str. 8, Bucharest \\ radu.carp@fspub.unibuc.ro \\ Andra Karla Sienerth \\ University of Bucharest, Faculty of Political Science \\ Spiru Haret str. 8, Bucharest \\ andrakarla@ymail.com
}

Received on 5 December, 2014; accepted on 29 December, 2014

doi:10.13165/JUR-14-21-4-14

\section{Introduction - Decentralization in the framework of public administration reform}

Administrative reform is one of the most used plans that almost all governments have experienced in order to increase the administrative capacity and to carry out public policy choices that are highly demanded. Administrative reform is considered to be the hallmark of governmental actions that leads to change, transformation and new opportunities ${ }^{1}$. As the Romania's recent experience proves, very often administrative reform fails for different reasons ${ }^{2}$.

1 Klimovsky, D. Local Public Reforms in Central and Eastern Europe: Agendas for the Future? In Iancu, D.-C. (ed.). Local Reforms in Transition Democracies. Iaşi: Institutul European, 2013, p. 11. Farazmand, A. Public Sector Reforms and Transformation: Implications for Development

Jurisprudencija/Jurisprudence

(c) Mykolo Romerio universitetas, 2014

(C) Mykolas Romeris University, 2014
ISSN 1392-6195 (print), ISSN 2029-2058 (online) http://www.mruni.eu/lt/mokslo_darbai/jurisprudencija/ http://www.mruni.eu/en/mokslo_darbai/jurisprudencija/ 
Decentralization is considered to be a prerequisite of democracy ${ }^{3}$, used as a key term for assessing the democratization of a political regime.

- In order to asses if an administrative reform, as deepening centralization, may determine a positive outcome, some requirements have to be fulfilled:

- External pressure - Central and East European countries were under pressure to introduce administrative reforms. Although it was not required by the adoption of the EU acquis, one important requirement was to increase the "administrative capacity" that put a pressure on the whole institutional architecture of the local public administration;

- Internal dissatisfaction - a feeling that everything needed to be improved that was a motivation for initiating and maintaining the reform;

- A reform strategy;

- A mechanism for managing reform;

- Feedback and evaluation.

Decentralization may help governments to balance regional development, to improve local policy-making processes and to empower communities or other decentralized units. It is also an important asset in order to mobilize more resources, not only from the public, but also from the private sector ${ }^{4}$. Decentralization is defined as the state's readiness to transfer its competences due to its own lack of interest or ability to perform them efficiently within timely manner ${ }^{5}$.

According to some authors ${ }^{6}$, there are four forms of decentralization:

- Political decentralization - the transfer of power to citizens and elected representatives from the local level;

- Spatial decentralization - formulating policies that aim to reduce excessive urban concentration and to promote regional growth poles;

- Market decentralization - creating the framework for developing local goods and services;

- Administrative decentralization - changing the hierarchal and functional distribution of powers from the central to the local government.

Administration. In Huque, A.S., and Zafarullah, H. (eds.). International Development Governance. New York: Taylor \& Francis, 2006, p. 546.

3 Nabaldian, J. Facilitating Community, Enabling Democracy: New Roles for Local Government Managers. Public Administration Review. 1999, 59(2): 187-196.

4 Rondinelli, D. A. Decentralization and Development. In Huque, A.S., and Zafarullah, H. (eds.), op. cit., p. 395.

5 Treisman, D. Defining and Measuring Decentralization: A Global Perspective [interactive]. [accessed on 2014-12-05]. <http://www.sscnet.ucla.edu/polisci/faculty/treisman/Papers/defin.pdf >.

6 Cohen, J.M., and Peterson, S.B. Administrative Decentralization. Strategies for Developing Countries. West Hartford: Kumarian Press, 1999, p. 22-23; Klimovsky, D., and Lackova, Z. Local Policy Making: Actors and Tools. In Klimovsky, D., and Radzik-Maruszak (eds.). Selected Aspects of Local and Regional Development. Nova Gorica: School of Advanced Social Studies in Nova Gorica, 2012, p. 113. 
To evaluate an administrative reform as a further step towards decentralization in a country, it is necessary to frame that reform in a model, part of the models that were developed in the last decades:

- New Public Management reform - successfully implemented in the United Kingdom;

- Welfare state policy reform - the purpose of this reform is to cut the expenditure, by any means;

- Institutional reform - a mixture of privatization, de-bureaucratization and decentralization that was experienced in countries, such as Belgium or Italy;

- Regime reform - public sector reform has been initiated in the same time as decentralization in countries, such as Portugal and Spain, after the democratization process started;

- Comprehensive reform - all the administrative reforms were consensual and were initiated together with experimental proceedings, such as the case of Germany;

- Gradualist reform - the public sector has been transformed in a nonconsensual way through new legislation, as shows the case of the UK at the beginning of the 1980s;

- Transformation without reform - some local communities changed their way of decision-making without any reform strategy from the central government;

- Non-reform - countries, such as Austria, Luxembourg or Switzerland, did not want to initiate any public administration reform because they evaluated the current state of affairs in a very positive way ${ }^{7}$.

\section{Decentralization as part of the Central and East European countries reforms}

The administrative transformation of Central and East European countries cannot be excluded by any of these models ${ }^{8}$, it is a rather a combination of all of them. These countries started the reforms with different historical and cultural legacies and with different experiences of central planning. They were ill-equipped in the 1990s for a functional model of local administration because of the public administration structures inherited from the former regimes.

The administrative reforms in Central and East European countries are part of a broad process of decentralization in the world ${ }^{10}$. In the past two decades, $80 \%$ of all

7 Toonen, T.A.J. Administrative Reform: Analytics. In Peters, G.B., and Pierre, J. (eds.). The Handbook of Public Administration. Washington: Sage, 2007, p. 301. Transitions from Authoritarianism: The Role of Bureaucracy. Westport: Praeger, 2002, p. 7.

9 Klimovsky, D., op. cit., p. 15.

10 Selee, A.D., and Tulchin, J.S. Decentralization and Democratic Governance: Lessons and 
countries in the world experienced administrative reforms having decentralization as a purpose ${ }^{11}$.

The research conducted by Claessens and Djankov underlines the Central and East European countries' efforts to achieve decentralization, but concludes that vertical decentralization (increasing the number of decision-making tiers) does not lead to greater accountability of the administration ${ }^{12}$. Overall results are not satisfactory: according to another author, "although expenditures have been decentralized, revenues have remained fairly centralized, even two decades after the transition to democracy"13.

Previous research has focused on the proclivity to decentralization, some scholars arguing that it is linked, on the one hand, to the institutional development, subject to criteria, such as credibility and liberalization, and, on the other hand, to the physical and demographic conditions in each country ${ }^{14}$. In this model, there is a positive correlation between the two dimensions and the proclivity to decentralization, and the countries from the former communist block can be grouped into several categories (Table 1).

Table 1. Expected proclivity to decentralization

\begin{tabular}{|c|c|c|c|}
\hline \multirow{4}{*}{$\begin{array}{l}\text { Physical and } \\
\text { demographic } \\
\text { characteristics }\end{array}$} & & \multicolumn{2}{|c|}{ Institutional development } \\
\hline & & Relatively weak & Relatively strong \\
\hline & $\begin{array}{l}\text { Higher need } \\
\text { for decentrali- } \\
\text { zation }\end{array}$ & $\begin{array}{l}\text { Ukraine, Russia, } \\
\text { Belarus, Kazakhstan, } \\
\text { Uzbekistan, Azerbaijan }\end{array}$ & $\begin{array}{l}\text { Poland, Czech } \\
\text { Republic, Hungary, } \\
\text { Romania, Bulgaria }\end{array}$ \\
\hline & $\begin{array}{l}\text { Lower need for } \\
\text { decentrali- } \\
\text { zation }\end{array}$ & $\begin{array}{l}\text { Armenia, Georgia, Mol- } \\
\text { dova, Turkmenistan, Tajiki- } \\
\text { stan, Kyrgyzstan, Albania, } \\
\text { Bosnia \& Herzegovina }\end{array}$ & $\begin{array}{l}\text { Slovakia, Latvia, } \\
\text { Lithuania, Estonia, } \\
\text { Croatia, Macedonia, } \\
\text { Slovenia }\end{array}$ \\
\hline
\end{tabular}

Source: Dunn and Wetzel (2000)

Challenges. In Oxhorn, P., Selee, A.D., and Tulchin, J.S. (eds.). Decentralization, Democratic Governance, and Civil Society in Comparative Perspective: Africa, Asia, and Latin America. Washington: Woodrow Wilson Center Press, 2004, p. 295.

11 Crook, R., and Manor, J. Democratic Decentralization. Working Paper. Washington, D.C.: World Bank, 2002.

12 Claessens, S., and Djankov, S. Politicians and Firms in Seven Central and Eastern European Countries. Policy Research Working Paper Series 1954. Washington, D.C.: World Bank, 1998.

13 Barati-Stec, I. Hungary: An Unfinished Decentralization? IMFG Papers on Municipal Finance and Governance, Institute of Municipal Finance \& Governance. Munk School of Global Affairs, University of Toronto, 2012, p. 2.

14 Dunn, J., and Wetzel, D. Fiscal Decentralization in Former Socialist Economies: Progress and Prospects. Washington DC: World Bank, 2000, p. 6. 
Other authors argue that fiscal evidence (e.g., share of public expenditure/ consumption at subnational levels) tends to contradict this matrix, and thus, more qualitative indicators on governance are needed in order to assess this proclivity to decentralization ${ }^{15}$.

The institutional development was linked to the communist legacy, and the starting point was what scholars called "democratic centralism" and "homogeneous state authority"16. Therefore, administrative rearrangements became a major task of post-1990 governments in the whole region. In Hungary, which shared a similar evolution of the administrative reform as Romania, the process may be divided into different stages: the first is the creation of the appropriate framework for a decentralized system, the second one is the achievement of a sufficient public accountability as part of the EU accession process, and the last one is considered to be the recentralization of some responsibilities and finances ${ }^{17}$. In Bulgaria, the process of reforming the administrative system started with the democratic Constitution adopted in 1991, followed by other legislative regulation, a relevant one being the Decree No. 36 of the Council of Ministers from February 1998, establishing a strategy for modernizing the Bulgarian state by implementing a new administrativeterritorial organization based on increased powers for the local governments ${ }^{18}$. In Slovakia, decentralization started in 1998 with the creation of a new, regional and self-government tier of the government. The higher territorial units (zupy) emerged in 2001 and first elections were held in the same year. Decentralization efforts were supplemented with modernization, meaning more attention to management and education. However, the Slovak case of local government reform is "a story of both progress and regress" and it seems that the whole reform is "an unfinished step forward" 19 because of the municipal self-government fragmentation. In Slovenia, if the establishment of a regional level of government is considered to be an indicator of decentralization, there was no such a process in that country ${ }^{20}$, because so far the state

15 Petak, Z. How to Measure Decentralization: The Case-Study from Central European Countries. Paper presented at the 'Building Social Capital and Self-Governing Capabilities in Diverse Societies’ Workshop, Indiana University, Bloomington, June 2004.

16 Illner, M. Territorial Decentralization: An Obstacle to Democratic Reform in Central and Eastern Europe. In Kimball, J. (ed.). The Transfer of Power: Decentralization in Central and Eastern Europe. Budapest, 1998, p. 7-42.

17 Barati-Stec, I., art. cit., p. 3.

18 Boev, J. Bulgaria: Decentralization and Modernization of Public Administration. In Peteri, G. (ed.). Mastering Decentralization and Public Administration Reforms in Central and Eastern Europe. Budapest, 2002, p. 95-97.

19 Jacko, T. Public Administration and Local Government Reform in Slovakia - An Unfinished Step Forward. In Iancu, D.-C. (ed.), op. cit., p. 107.

20 Lajh, D. Slovenia. Nations in Transit 2011: Democratization from Central Europe to Eurasia [interactive] [accessed on 2014-12-05]. <http://www.freedomhouse.org/sites/default/files/ inline_images/NIT-2011-Slovenia.pdf>. 
level has not transferred any of its own competences to the local level - municipalities are executors of some state competences in local environment ${ }^{21}$.

There are some reasons why administrative reforms, especially decentralization, could fail: lack of political consensus on these reforms; bad reform design; the changing and contradictory assessment of external organisations. These reasons are important to underline, in order to understand what may be achieved and through what means ${ }^{22}$. As the case of Romania proves, a bad reform design, not in line with constitutional requirements, could lead to the abandon of the decentralization reform.

\section{Decentralization in the current Romanian constitutional and normative framework and some theoretical accounts}

\subsection{The constitutional and the normative frameworks}

This article focuses on the development of decentralization within the Romanian administrative system. According to a research ${ }^{23}$ on the developments in this field from the early 1990s until 2004, this process can be divided into four main stages: the first stage is characterized by changes within the structure and funding of local authorities, the second one is focused on transforming the administrative and financial decentralization into a key priority for the Romanian reform of the state. What concerns the third stage, new regulations regarding utilities and public services are adopted, and the last one refers to the phase after 2004, when a package of new legislative provisions was adopted in order to continue and accelerate the process of decentralization (e.g., the Framework Law on Decentralization No. 339/2004, the Government Decision No 2201/2004 on the Inter-ministerial Technical Committee and Working Groups on Decentralization).

Decentralization is mentioned in the 1991 Constitution in Article 120, which states that "public administration in territorial-administrative units is based on the principles of decentralization, local autonomy and devolution of public services". The Constitution is confined to enumerate these principles, without actually defining them. The law on local administration No. $215 / 2001^{24}$ resumes the provision of

21 Pinterič, U., and Prijon L. Two Decades of Decentralization Failures in Slovenia. In Iancu, D.C. (ed.), op. cit., p. 113.

22 Verheijen, A.J.G. Public Administration in Post-Communist States. In Peters, G.B., and Pierre, J. (eds.), op. cit., p. 317.

23 Profiroiu, M., and Profiroiu, A. Decentralization Process in Romania. Transylvanian Review of Administrative Sciences. 16 E/2006, p. 117-118. 
the Constitution and adds three principles: the eligibility of local authorities, the legality and public consultation in solving local issues of high concern (Article 2.1). The Framework Law on Decentralization was adopted only in 2004, following the expression of the need for such a law by the Venice Commission, upon the issuance of the revision of the Constitution from $2003^{25}$. The 2004 Law was preceded by the adoption of a Government Decision regarding the Updated Strategy of the Romanian Government on accelerating public administration reform ${ }^{26}$, which identifies multiple objectives linked to decentralization, including the creation of an appropriate regulatory framework ${ }^{27}$. For almost 10 years, there have been several attempts to start the process of decentralization, but neither Law of 2004, nor that of 2006 was implemented according to the parameters they were designed to, and the attempt in 2013 to take concrete steps towards decentralization was declared unconstitutional.

\subsection{The theoretical approach on decentralization in Romania}

The issue of decentralization is widely debated in the Romanian public law doctrine. Thus, it is considered that administrative decentralization requires "the existence of local public officials elected by the local community, with their own powers, directly intervening in the management and administration of community issues involving local autonomy", and its elements are the legal personality, solving their own affairs and local autonomy ${ }^{28}$. According to another view, decentralization is the system that is based on the recognition of local interest, distinct from the national one, the settlements having their own administrative apparatus, subordinated to local interest ${ }^{29}$. Decentralization is characterized, according to a different author, by the following elements: local authorities are autonomous public officials, elected by local territorial communities; they have their own decision-making power; local communities have their own administrative, as well as material, financial and human resources ${ }^{30}$. The consequence of decentralization is the transfer of public services of regional interest from the competence of the center to the authorities of local public administration ${ }^{31}$. It has been argued that "decentralization is not the opposite of centralization, but rather its reduction, the decrease of concentration of

25 European Commission for Democracy through Law (Venice Commission). Opinion on the Draft Revision of the Constitution of Romania. CDL - AD (18 March 2003).

26 Official Gazette No. 542/ 17 June 2004.

27 For a presentation of this strategy, see Carp, R. Strategii şi propuneri de reformă a administraţiei publice în perspectiva integrării europene. Revista de drept public. 2/2006, p. 102-115. Apostol Tofan, D. Drept administrativ. Vol. I, 2nd edition. Bucureşti: CH Beck, 2008, p. 254.

29 Popa, E. Autonomia locală în România. Bucureşti: All Beck, 1999, p. 121.

30 Santai, I. Drept administrativ şi ştiinţa administraţiei. Vol. I. Sibiu: Editura Universităţii Lucian Blaga, 1998, p. 215-216.

31 Ionescu, C. Tratat de drept constituţional contemporan. Bucureşti: All Beck, 2003, p. 97. 
powers" ${ }^{32}$. It is considered that any administrative authority, except those involving the exercise of specific attribution by a single person (President, Prime Minister), may be placed in a state of devolution or one of decentralization ${ }^{33}$. According to another author, "decentralization is not an end in itself but a means that facilitates bridging the gap between the level of decision-making and the ones that will bear its consequences". From the same perspective, decentralization allows the "achievement of the requirements of other principles that are fundamental values of society, such as fairness, insurance of freedom and equality among citizens" 34 . The doctrine distinguishes between territorial decentralization and the technical one. The former implies the existence of common interests of the residents within a specific geographic area and implies "the existence of elected local authorities who have general material competence". The latter implies the existence of public law entities providing public services, called "local public establishments". Decentralization is seen from this perspective exclusively as an administrative issue, unlike federalism, which is a political issue: public authorities benefiting from decentralization operate within a unitary state ${ }^{35}$. According to a similar view, decentralization in Romania, as provided by the Constitution, is exclusively administrative, unlike that in Italy, which led to a regionalized state, or the one in Belgium that resulted in a federal state ${ }^{36}$. Another opinion along the same line is that there are two types of decentralization: a political one - federalism, and an administrative one, federalism being "the most profound form of decentralization" 37 . The distinction between territorial decentralization and the technical one derives from another distinction between territorial decentralization and that of services ${ }^{38}$.

\subsection{The Framework Law No. 339/2004 on Decentralization}

According to the Framework Law No. 339/2004 ${ }^{39}$ on Decentralization, decentralization is defined as "the transfer of administrative and financial authority and responsibility from central to local level". The law listed the principles to be

33 Muraru, I., and Tănăsescu, E.S. (eds.). Constituţia României - comentariu pe articole. Bucureşti: CH Beck, 2008, p. 1156-1157.

34 Vrabie, G., and Bălan, M. Organizarea politico-etatică a României. Iaşi: Institutul European, 2004 , p. 32 .

35 Iorgovan, A. Tratat de drept administrativ. Vol. I, 4th edition. Bucureşti: All Beck, 2005, p. 453.

36 Vrabie, G., and Bălan, M., op. cit., p. 33.

37 Apostol Tofan, D., op. cit., p. 254-255.

38 Tarangul, E. D. Tratat de drept administrativ roman. Cernăuţi : Tipografia Glasul Bucovinei, 1944, p. 74. For an account of this distinction, see Petrescu, R. N. Drept administrativ. București: Hamangiu, 2009, p. 55. 
followed in implementing the decentralization process (Article 4), including the principle of subsidiarity ${ }^{40}$, equality of citizens in front of the local authorities, exercise of powers by local authorities at the administrative level closest to the citizen, insurance of a balance between administrative decentralization and financial decentralization in each administrative-territorial unit, transparency of decisions, providing financial decentralization based on transparent rules regarding the calculation of financial resources assigned to administrative-territorial units.

It can be noticed that all these principles are very general and not related to how central or local administration subsequently functioned after the enactment of this law. Subsidiary is just mentioned, not defined, and thus, ineffective. Decisionmaking at a level closer to the citizen or what Guy Héraud called "exact suitability"41 actually overlaps with the principle of subsidiary. It is not clear what the law referred to when mentioning the insurance of a balance between administrative and financial decentralization. It would have been appropriate to clarify that any new power assigned to the lower administrative level must be accompanied by an indication of the financial implications, so that there are no powers that cannot be exercised after being delegated.

This law states that the local authorities have the right to experiment, defined as the ability of local government to organize pilot centers for the implementation of decisions regarding the decentralization of powers from central to local level, before their mainstreaming at national level (Article 6). It was intended for certain powers to be delegated to authorities of the local public administration for a specific period of time, before either withdrawing or extending them at national level, if successfully implemented. The competences transfer experience concerns solely the unique powers of the central administration, while subsidiarity concerns the establishment of competent authority, in case of shared competences between the central and local levels. These pilot centers were not established under the Law No. 339/2004 because there were no details concerning their establishment and status. Since the adoption of this law, the right to experiment and the setup of pilot centers were considered as very difficult to implement and intended to remain at the stage of good intentions ${ }^{42}$. It is not clear what was meant by these pilot centers: conducting impact assessments on the implications of decentralization of certain competences or even their decentralization

40 For a presentation of the principle of subsidiarity, see Millon-Delsol, C. L'Etat subsidiare. Paris: Presses Universitaires de France, 1992. For a more recent presentation, with the newest contributions on the topic, see Craig, P. Subsidiarity: A Political and Legal Analysis. Journal of Common Market Studies. 2012, S1(50): 72-87. For a presentation of subsidiarity within the Romanian legislation and its application at European level, see Carp, R., Gal, G.D., Mureşan, S., and Preda, R. În căutarea binelui comun. Cluj-Napoca: Eikon, 2008, p. 59-72.

41 Héraud, G. Le fédéralisme. Nice: Presses d'Europe, 1995, p. 12.

42 Carp, R. Strategii şi propuneri de reformă a administraţiei publice în perspectiva integrării europene, op. cit., p. 114. 
and tracking the effects of such an arrangement. The mechanism by which certain powers and not others are selected to be decentralized was not clearly indicated. It should be noted that the right to experiment is not included in the European Charter on Self-Government.

The same law stated that local authorities may decide to establish collaborative bodies to which they can transfer part of their competences (Article 17, paragraph 1). Can such bodies other than those specified in the Constitution at the "Local Government" chapter (Articles 120-123) - mayors, city councils, county councils, county council presidents - be set up? In the authors' opinion, although the Constitution does not make an exhaustive list of these authorities, it also does not indicate the possibility of establishing others by law. If the constituent legislator had wanted other authorities to be established by the law, it would have specified this. The Constitution enlists some of the competences of local public authorities. The setup of new bodies, besides those enlisted in the Constitution, encompassing also the competences delegated from other authorities (which can only be those listed in the Constitution), raises serious problems of compatibility with the Constitution.

The Law No. 339/2004 lists the underlying rules for the process of decentralization (Article 19). The first step would have been the development of a Governmental Strategy to accelerate public administration reform. The next step would have been, according to Article 20, the creation of technical structures for the implementation and monitoring of the whole process (Inter-Ministry Technical Committee, working groups in each ministry, county and possibly cross-county technical committees). Subsequently, measures were to be established and pilot phase to be conducted and the last stage would have been monitoring the results, based on a system of performance indicators approved by Government Decision.

\subsection{The Framework Law No. 195/2006 on Decentralization}

Two years later, a new law came into force - Framework Law No. 195/2006 on Decentralization ${ }^{43}$, which repealed completely the Law No. 339/2004. It is not clear why a new law was opted for, without the previous being implemented. This law offers more definitions than the previous one (Article 2). A new definition of decentralization is given, different from the original one, in that the transfer of powers from the central government to the private sector would also fall under the category of decentralization, just like the transfer to the local authority. The principle of subsidiarity is not only mentioned, but clearly defined in Article 3. Administrative capacity is defined, for the first time in Romanian law, as "all the material, institutional and human resources available to the administrative-territorial unit, as well as the 
actions it conducts for the exercise of competences provided by law"44. Thus, the legislature has chosen to draw a connection between subsidiarity and administrative capacity. By the way it defines subsidiarity and link to the administrative capacity, the Framework Law on Decentralization provides an understanding of subsidiarity contrary to the generally accepted definition of this concept ${ }^{45}$. Subsidiarity is the principle of separating the competences that are exercised by the two entities, if these competences are shared, the upper level being able to intervene only if the lower one cannot. There may be cases in which the lower level cannot intervene not due to the lack of resources, but due to the "the scale or effects of the proposed action", as mentioned in Article 5 of the Treaty on European Union.

The principles on which the process of decentralization must be conducted are listed differently in the Law No. 195/2006 (Article 3) than in the Law No. 339/2004: the principle of subsidiarity; the principle of ensuring resources adequate to the competences transferred; the principle of responsibility of local government authorities in relation to their powers; the principle of ensuring a process of decentralization that is stable, predictable, based on objective rules and criteria; the principle of equity that involves ensuring access of all citizens to public services and public utility services; the principle of budgetary constraint prohibiting the use of special transfers or subsidies by the central government to cover the final deficits of local budgets ${ }^{46}$.

The Law No. 195/2006 defines the competences delegated, i.e., exclusive and shared and the concept of devolution. The latter is understood as the redistribution of powers (between central authorities and specialized territorial structures), unlike decentralization that means the transfer of competences.

The Law No. 339/2004 refers to the process of decentralization primarily in terms of procedure and pays less regard to the substantive issues related to the practical method of the transfer of competences, which is subject to decentralization. The Law No. 195/2006 is built on the same approach, but is more elaborate. According to this law, decentralization means the transfer of competences, based on the subsidiarity principle and on criteria, such as economies of scale (reducing the unit cost of public service with the growing number of those who benefit from it) and the geographic

44 This definition is similar to other definitions from the literature. For definitions, see Addison, H. J. Is Administrative Capacity a Useful Concept? Review of the Application, Meaning and Observation of Administrative Capacity in Political Science Literature [interactive]. [accessed on 2014-12-05]. <http://personal.lse.ac.uk/addisonh/Papers/AC_Concept.pdf>.

45 Romanian doctrine does not define properly the subsidiarity principle, taking into account all its features. According to Bălan, this principle supposes that the process of taking decisions in the public interest descends to the lowest level, and therefore, this process would not be a monopoly or a rule for the public administration (Instituţii administrative. Bucureşti: $\mathrm{CH}$ Beck, 2008, p. 60).

46 For a description of these principles, see Vedinaş, V. Drept administrativ. 4th edition. Bucureşti: Universul Juridic, 2009, p. 386. 
scope of the beneficiaries (place of residence of the beneficiaries of the decentralized public service) (Article 4).

The issue of economies of scale, reflected in the provision of public utility services by local authorities, has been relevant to both older and newer democracies. If countries, such as Denmark, Sweden, the Netherlands, Germany or Canada, recurred to forced amalgamations in order to cope with the resource pressure for such services, former communist countries, such as Hungary and the Czech Republic, had to overcome the negative past experiences of forced cooperation among municipalities in the detriment of small villages. According to Barati-Stec, in Hungary, where local authorities were compelled by Act XCV (1990) to supply public utility services "as a result of this history, voluntary municipal associations were favored by the state subsidy system in the early 1990s. [...] The central government's tool for encouraging municipal associations is not to give them direct subsidies, but rather to threaten them with lower subsidies if they do not form an association" ${ }^{47}$. A similar pattern of fragmentation is witnessed by the Czech Republic, particularly in the early years of transition: "many municipalities that had been amalgamated in the earlier years split again into their original parts. The previous amalgamation was rejected as an act of centralism by the municipalities involved, and the renewal of their political and administrative identity was viewed as a priority in the restoration of local democracy. Criteria governing economic and organizational rationality seldom played a role in such decisions" 48 .

According to Article 5 of the Law No. 195/2006, the transfer of competences is based on impact assessments and the central public administration, in collaboration with local authorities' associative bodies, which organize pilot stages to test the impact of the proposed solutions. It is no longer pilot centers, as in the previous framework law, but merely pilot phases (also mentioned in the previous law in Article 19(d)), which shows that it was desired not to resort to creating new institutions.

The Law No. 339/2004 made the connection between the administrative and financial autonomy, but the Law No. 195/2006 refers to this issue in a more coherent way: "the transfer of competences is done concomitantly with the provision of the necessary resources to exercise them. The exercise of competences occurs only after the submission of the necessary financial resources" (Article 6, paragraph 1).

Experiences from other CEE countries highlight the importance of the complementary allocation of responsibilities and resources between the different administrative layers. For instance, in Hungary, as Barati-Stec highlighted, Act XCV (1990) placed the burden of supplying public services on the counties, which in turn were not allowed to conduct their own fiscal policies and raise revenues. In Poland,

47 Barati-Stec, I., art. cit.

48 Illner, M. Territorial Decentralization: An Obstacle to Democratic Reform in Central and Eastern Europe, op. cit., p. 22. 
on the other hand, municipalities - which are the main administrative-territorial units - did not face similar constraints in providing public services, due to the fact that the reform has granted them the right to generate their own revenues through taxes, loans, bonds, etc. ${ }^{49}$ Thus, in this logic, the transfer of competences can only occur simultaneously with the transfer of financial resources, which may be higher than the original ones, if such a solution is required.

The Law No. 195/2006 introduced a mechanism absent in the previous law: the establishment of cost standards (for the financing of decentralized public services and public utility services) and quality standards (to ensure their provision by local authorities) (Article 9). The task of establishing such standards is laid upon the Government, and these standards must be used to determine the amounts pertaining to local authorities. The standards were designed to be uniform at the level of all these authorities. Only 3 years after the entry into force of this law, Government Decision No. 961/2009 concerning the adoption of the Framework guided for minimum quality standards and minimum cost standards for decentralized public services ${ }^{50}$.

Another innovation of the law is related to administrative capacity. Depending on whether or not there is the administrative capacity, the administrative-territorial units are classified in category I and category II (Article 10). Lack of administrative capacity results in exclusion from the transfer of competences until the existence of this capacity can be proven. Administrative capacity assessment criteria are set by the central government, in collaboration with the associative structures of local public administration.

The Law No. 195/2006 also established a complete catalogue of exclusive competences (Articles 20-22), of those shared (Articles 23-26) and of those delegated (Articles 27-28). A detailed list of these types of competences lacks in the Law No. 339/2004.

This law was designed to be applied in conjunction with the general strategy and sectorial strategies of decentralization and with the definition of cost and quality standards. Also, an annual report on the status of the decentralization process was expected to be issued by the Ministry of Interior.

\subsection{The issue of decentralization in the European Charter of Local Self-Government}

Neither the Law No. 339/2004, nor the Law No. 195/2006 was designed taking into account an international document that is relevant to decentralization: the European Charter of Local Self-Government of the Council of Europe, ratified by

49 Prisecaru, P. Regional Governance and Policy in Transition Countries. A Comparative Analysis of the Polish and Romanian Cases. In Stanomir, I., Manolache, C., and Gheorghe, A. (eds.). Challenges of Transition. The-Post Communist Experience(s). Iaşi: Institutul European, 2014, p. 41-43. 
Romania by Law No. 199/199751. Even if the subject of this Charter is local autonomy, some principles that any regulation on decentralization should take into account are included:

- The exercise of public responsibilities should fall upon the authorities that are closest to the citizens, and the allocation of a responsibility to another authority (as is the case of decentralization) should take into account the extent and nature of the task, as well as the efficiency and economy. Article 4 of the Law No. 339/2004 refers to the first aspect, so does Article 3 of the Law No. 339/2006 when referring to the definition of subsidiarity. The establishment of cost and quality standards referred to in Article 9 of the Law No. 195/2006 transpose the requirements of efficiency and economy;

- Local authorities should be consulted on decisions that directly affect them. This principle does not appear in the Romanian legislation on decentralization;

- The administrative control of local government should be exercised with consideration to the proportionality between the extent of intervention of the controlling authority and importance of the interests it seeks to protect. The principle of proportionality is not listed in the Romanian legislation on decentralization;

- The proportionality of the financial resources of local authorities and the competences of that authority, as defined by the Constitution or by law. Article 4 of the Law No. 339/2004 refers to this principle, in a wording that significantly alters its meaning when it states the principle of ensuring a balance between the administrative and financial decentralization, and Article 6 of the Law No. 195/2006 envisages the same principle when establishing the rule that the transfer of competences is done concomitantly with the insurance of the necessary resources;

- The allocation of grants (from the central administrative authorities or other entities) must not obstruct local government authorities to define their own policies. The principle of ensuring a decentralization process that does not constrain the activity of the local government or limit the local financial autonomy (Article 3 of the Law No. 195/2006) can be considered an equivalent, but only partially, of this principle from the Charter;

- Recognition of the right of association between local authorities. The manifestation of this right of association consists of the possibility of local authorities to decide on the establishment of collaborative bodies between administrativeterritorial units (Article 17 of the Law No. 339/2004).

\section{The 2013 Draft Law on Decentralization}

In 2013, the Parliament passed the Law on establishing measures of decentralizing certain competences exercised by some ministries and specialized agencies of the 
central government, as well as of public administration reform measures ${ }^{52}$. The law was not intended to repeal the Framework Law No. 195/2006 on Decentralization. This law was declared unconstitutional by Decision No. 1/2014 of the Constitutional Court $^{53}$. It is worthwhile noting that this law, in spite of being very extensive (49 pages in the version passed by the Parliament), does not refer to the Framework Law on Decentralization in force, or to the European Charter of Local Self-Government.

This law is a combination between the certain amended laws change and some new provisions. Thus, it was intended to amend and supplement the following laws: Law No. 273/2006 on Public Finances and Law No. 213/1998 on Public Property; Law No. 422/2001 on the protection of historic monuments; Government Ordinance No. $43 / 2000$ on the protection of archaeological heritage and designation of archaeological sites as areas of national interest; Government Ordinance No. 58/1998 on the organization of tourism activity in Romania; Law on national education No. 1/2011; Government Ordinance No. 195/2005 on environmental protection; Government Ordinance No. 23/2008 on fisheries and aquaculture; Government Ordinance No. 19/2006 on the use of the Black Sea beach and the control of beach activities; Government Ordinance No. 107/2002 on the establishment of the "Romanian Waters" National Administration; Law No. 95/2006 on healthcare reform; Physical Education and Sport Law No. 69/2000.

Notwithstanding Law No. 213/1998 on Public Property, some public property assets under the management of ministries, government agencies or decentralized services were supposed to be transferred to the public domain of the counties and placed council administration under the county. The assets that were supposed to be subject to a transfer would have maintained their previous destination, but the local authorities would have had the opportunity to change the destination after carrying out a similar investment. Furthermore, the administrative-territorial units would have been enabled to transfer among themselves the ownership/administration rights over the assets taken over as a result of the law, through the adoption of local/county council decisions. The staff of public institutions and decentralized structures would have been taken over by the ministries concerned by the local authorities, based on takeover protocols.

\section{The opinion of the Constitutional Court on the 2013 Draft Law on Decentralization}

In the complaint filed with the Constitutional Court, it was considered that the following articles of the Constitution were breached: Article 1, paragraph 1; Article 
102, paragraph 1; Articles 120-122; Article 123; Article 136; Article 1, paragraphs 3 and 5. The complaint also included extrinsic criticism of unconstitutionality based on the manner in which the Government had assumed responsibility over this law, but these criticisms were rejected by the Constitutional Court.

The Constitutional Court answered extensively to the objections. Referring to criticism based on the breach of Article 1, paragraph 1 of the Constitution, the Court rejected this claim, arguing that there is no contradiction between the unitary character of the state and the constitutional regulation of decentralization. In connection with the violation of Article 1 paragraphs 3 and 5 on the rule of law, the Constitution, its supremacy and the laws, the Court provided an extensive argument in many parts of the decision. In the first approach, the Court held that this law was passed in violation of the Framework Law No. 195/2006, which constitutes a breach of the constitutional provisions (Article 1, paragraph 5) on the obligation of compliance with the laws. Specifically, the Court held that the law does not comply with Article 5, paragraph 1 of the Framework Law No. 195/2006, which states that "the transfer of competences is based on impact analyses and it is realized on specific methodologies and monitoring indicator systems". In deciding whether or not to apply this provision, the Court requested justifying documents to the government. Among those submitted, none were considered "to have the legal significance of a study/impact assessment", which "provides evidence that the obligations undertaken by the Government and Parliament [...] to create, namely to adopt the law criticized on the necessary impact analyzes". The Court also noted that the cost standards, mandatory under Article 9 of the Law No. 195/2006, were developed "not even at the estimated level". According to the Court, the transfer of competences did not comply with the framework imposed by the Law No. 195/2006 "in terms of clarity, precision and foreseeability of the norm". The Court detailed its arguments, analyzing the decentralization measures from the law, depending on each area:

- Agriculture and rural development: the Court considered that the measures of the law are unclear, and that in this field "the legal status of components to be decentralized and the reason why certain components are planned to be decentralized, and others do not" remains unclear. Therefore, these measures "do not meet the constitutional requirements regarding the quality of the law in terms of clarity, precision and predictability, and therefore the addressee of the regulation does not know the legal regime of the institutions/authorities that are to be reorganized, with severe consequences on the organization and operation of the new structures, nor does it know precisely which institutions' activities are subject to control, verification or monitoring. Hence, it is a matter of principle that the law should be clear, precise and predictable; moreover, given the importance of the sector under consideration, these requirements must be strictly observed not to cause a divergent interpretation and application of the norm throughout the state"; 
- Culture: the Court considered that the measures of the law do not comply with Article 1, paragraph 5 of the Constitution, because "on the one hand, it amends, supplements and repeals the current legislation and, on the other hand, it regulates confusingly the issue of county directorates of for culture";

- Tourism: the provisions of the law reveal, according to the Court, "serious legislative technique problems with repercussions on the law's qualities, the addressee of the norm, either natural or legal persons, or central or local public authorities being unable to know [...] the conduct which they should adopt in connection with the ambiguous normative assumption of the law. Such a way of writing the text creates the premises of a discretionary application of the law by public authorities at the expense of natural or legal persons, as the case may be, and the infringement of Article 1, paragraph 5 of the Constitution, proving an inconsistency in the regulations presented in relation to the existing legal framework";

- Secondary education: the Court acknowledges the violation of Article 1, paragraph 5 of the Constitution;

- Environment: the same conclusion as the above stated one in the case of secondary education;

- Health: the Court considers that due to the vagueness of the legislation, it appears a "legal uncertainty about the structure of county public health departments and the status of their "leaders", in violation of Article 1, paragraph 5 of the Constitution;

- Youth and sports: the Court states that Article 1, paragraph 5 of the Constitution is breached due to the "incomplete and vague" character of the regulation; in addition, it notices the "unpardonable negligence in drafting a normative act [...] repeating within the same article of the law of a competence of the county directorates of sports and youth";

- Transport: starting from the premise that the transfer of the shares in "METROREX" SA in the private property of Bucharest Municipality does not constitute a measure of decentralization under the Law No. 195/2006, the Court finds a lack of correlation between the title of the law and the name of Title IX (on transport), on the one hand, and this provision, on the other hand, which is equivalent to a breach of the Law No. 24/2000, contrary to Article 1, paragraph 5 of the Constitution.

Regarding the violation of Article 102, paragraph 1 of the Constitution, the Court rejected this claim, holding that, in order to decide, it should conduct an opportunity analysis that exceeds its powers.

What concerns the violation of Articles 120-122 of the Constitution, the Constitutional Court considers that a law which seeks decentralization must consider two types of transfer, namely that of administrative jurisdiction and financial competence from central to local level. The Court found that, based on 
Government Decision No. 961/2009, the Government should have adopted the cost standards, prior to the assumption of responsibility. In the absence of the approval of the standards costs, "the transfer of financial competence appears to be illusory". Although the law includes some measures that can be subsumed under the concepts of "transfer of administrative competence" and "transfer of financial competence", the Court considers that there is a lack of "coordinated transfer of administrative and financial competence", which "can have serious effects on the effectiveness of the decentralization process".

Regarding the constitutional objection concerning the supposed violation of Article 123, the Court rejected it on the grounds that this rule has "a progressive understanding".

The Court's reasoning is extremely detailed in what concerns the objection that the transmission of assets' ownership from the public/private domain of the state to the public/private domain of the administrative-territorial units, respectively the means for establishing an administrative right in favor of local authorities, are embodied in provisions of law that are unconstitutional. Regarding the first point, based on the finding that the law establishes a mechanism of exemption from framework laws on property regime, the Court concludes that an exemption is not per se unconstitutional, but rather that the derogatory law "should not disaffirm the effectiveness of the constitutional provisions". The law's mechanism, without observing the due legal process and without proper individualization of goods, is contrary to the constitutional provisions (Article 1, paragraph 5 on complying with the Constitution and laws). Not only this provision, but also Article 120, paragraph 1 on the local autonomy is deemed by the Court as violated, since the transfer of ownership does not presume an agreement from the administrative-territorial units. What concerns the second aspect, the method of establishing a right of administration in favor of local authorities is regarded by the Court as "incompatible with the concept and characters of the real right of administration", and therefore, it contravenes Article 136, paragraph 4 of the Constitution. The provisions of the law concerning the right of administration are also considered to be imprecise, which, in the Court's view, is equivalent to violation of Article 1, paragraph 5 of the Constitution. The Court finds contradictions between the provisions of the law, the same categories of assets subject to a transfer of ownership being considered also subject to the assignment of a right of administration. The existence of conflicting legislative solutions and the cancellation of certain provisions of the same law with provisions of the Law are considered by the Court resulting in the "breach of the principle of legal certainty due to a lack of clarity and predictability of the norm", and this principle is considered "a fundamental dimension of the rule of law", stated by Article 1, paragraph 3 of the Constitution.

The Constitutional Court has developed the argument that it has jurisdiction to decide not only on the unconstitutionality of the law, but also on the inconsistency 
between it and the legal framework. The Court relied on its previous jurisprudence, which determined that the infringement of the law results in violation of Article 1, paragraph 5 of the Constitution (Decision No. 901/200954) and affects the rule of law (Decision No. 783/201255). Previous jurisprudence (Decision No. 903/2010 ${ }^{56}$, Decision No. $743 / 2011^{57}$, Decision No. $1 / 2012^{58}$, Decision No. $447 / 2013^{59}$ ) is used also for arguing that "any law must meet certain qualitative requirements", such as predictability, which means that it "must be sufficiently clear and precise in order to be applicable". This argument is useful to conclude that the law does not fall within the legal framework provided by the Law No. 195/2006 or any legislative framework in the field of property (the Civil Code, the Law on Public Property No. 213/1998, the Law on cadaster and real estate publicity No. 7/1996). The Court relied not only on its own jurisprudence, but also on that of the European Court of Human Rights (the phrase "prescribed by law" means not just a legal basis in domestic law, but also the quality of the law in question that must be accessible and predictable - Rotaru v. Romania ${ }^{60}$, Amann v. Switzerland ${ }^{61}$; the principle of legal certainty is one of the fundamental principles of the rule of law - Beian v. Romania ${ }^{62}$, Jordan Yordanov and Others v. Bulgaria ${ }^{63}$, Stefan and Others v. Romania ${ }^{64}$, Nejdet Şahin and Perihan Şahin v. Turkey ${ }^{65}$; Remuszko v. Poland ${ }^{66}$ ) and the Court of Justice of the European Union, in the sense that citizens who are the recipients of the law have legitimate expectations that must be respected - Willy Gerekens and Agricultural Association Protocol for the Promotion of Merchandising of the Dairy Products v. Grand Duchy of Luxembourg ${ }^{67}$, Criminal Proceedings against E. and $F^{68}$ ).

The Court concluded that the law subject to constitutional control "does not meet the constitutional requirements regarding the quality of the law". The Court considers that "compliance with laws is mandatory, but a legal entity cannot be expected to comply with a law that is not clear, precise and predictable, since it cannot

\footnotetext{
54 Official Gazette No. 503/ 21 July 2009.

55 Official Gazette No. 684/ 3 October 2012.

56 Official Gazette No. 584/ 17 August 2010.

57 Official Gazette No. 579/ 16 August 2011.

58 Official Gazette No. 53/ 23 January 2012.

59 Official Gazette No. 447/ 29 October 2013.

60 No. 28341/95, ECHR 2000 - V.

61 No. 27798/95, ECHR 2000 - II.

62 No. 30658/05, ECHR 2007 - V.

63 No. 23530/02.

64 No. 38155/02.

65 No. 13279/05.

66 No. 1562/10.

67 Case C - 459/2, Decision from 15 July 2004.

68 Case C - 550/09, Decision from 29 June 2010.
} 
adapt its behavior according to the normative assumption of the law", and therefore, "the legislature must pay attention when it passes a law". Therefore, the law does not comply with the quality requirement of the law, which also affects the principle of legal certainty, considered to be a dimension of the rule of law, and, hence, the consequence is the violation of Article 1, paragraphs 3 and 5 of the Constitution.

Given the above considerations, the Court upheld the objection of unconstitutionality in what concerns the intrinsic unconstitutionality and found that the law in its entirety is unconstitutional.

The Court held in this case that it is invested, through the constitutional review, to conduct also a legality check. As the Court itself noted in that decision, such choice corresponds to its previous jurisprudence - there have been situations where the Constitutional Court relied on Article 1, paragraph 5 in order to claim its competence in solving cases where breaking the law is at stake rather than the break of the Constitution. Explaining this option extensively by invoking not only its own jurisprudence, but also that of the ECHR or the ECJ, proves the particular attention the Court has paid regarding its option. An option that is questionable, however, since ordinary courts are invested with this type of control. What is more, any new law is "breaching" the old law, which does not mean that any new law is unconstitutional. The Court stated in its decision that compliance with a law is an obligation of citizens, but only if that law is "clear, precise and predictable". Therefore, the laws are not clear, precise and predictable, and are subject to constitutional review, and those who meet these standards cannot be subjected to this type of control. It would be desirable to clearly explain this distinction by the Constitutional Court in its future jurisprudence.

\section{Conclusions}

The account of decentralization, since the introduction of this concept in the Constitution of 1991 up to now, is extremely unsatisfactory. The transfer of powers from central to local levels, the essence of decentralization, was limited and was done mainly in a descriptive form of the competences of local authorities by the successive laws concerning the local administration. A gradual approach was preferred, extremely cautious regarding the implementation of decentralization. The European Charter on Local Autonomy, albeit transposed in Romanian law since 1997, had no influence on the drafting of two framework laws from 2004 and 2006, a rule that even the law from 2013 makes no exception to. In 2004, the principle of subsidiarity was lacking a definition and was treated distinctly from the "exact adequacy", with which it actually overlaps, whereas in 2006 it was defined, but the definition departed from the one commonly accepted at European level. Other principles, such as proportionality or consultation of local authorities on decisions that directly affect 
them, were not introduced in the Romanian legislation. Of course, it could be argued that all the principles of the Charter ought to be included, since it became part of domestic law once it was ratified, but there should have been at least a reference to the Charter in the two framework laws from 2004 and 2006. The 2013 law also makes no exception on this omission.

Until the attempt to conduct the transfer of competences in 2013, sanctioned by declaring the whole law as unconstitutional, an approach merely describing the principles and stages of decentralization was opted for. There is also the option to specify from the very beginnings which are the institutions which competences are to be transferred to a lower level due to decentralization, but this was not the case. This alternative was avoided, probably due to the finding of a weak administrative capacity that causes decentralization to result in institutions that cannot exercise their powers invested with. If the principle of subsidiarity were to be understood properly, the transfer of competences would have been adequately described. Unfortunately, it was not understood how to apply this principle, and the result was writing two successive laws, which are a mixture of general principles and technical guidelines that would have been more appropriate for a public policy strategy rather than in a normative act.

The subsidiarity principle is decisive in regard to the transfer of powers from central to local level and until it is understood that this principle cannot be separated from that of proportionality, any attempt to start the process of decentralization in Romania is doomed to failure.

\section{References}

Addison, H. J. Is Administrative Capacity a Useful Concept? Review of the Application, Meaning and Observation of Administrative Capacity in Political Science Literature [interactive]. $<$ http://personal.lse.ac.uk/addisonh/ Papers/AC_Concept.pdf $>$.

Apostol Tofan, D. Drept administrativ. Vol. I, 2nd edition. Bucureşti: $\mathrm{CH}$ Beck, 2008.

Baker, R. (ed.). Transitions from Authoritarianism: The Role of Bureaucracy. Westport: Praeger, 2002. Barati-Stec, I. Hungary: An Unfinished Decentralization? IMFG Papers on Municipal Finance and Governance,
Institute of Municipal Finance \& Governance, Munk School of Global Affairs, University of Toronto, 2012.

Bălan, E. Instituţii administrative. Bucureşti: CH Beck, 2008.

Boev, J. Bulgaria: Decentralization and Modernization of Public Administration. In Peteri, G. (ed.). Mastering Decentralization and Public Administration Reforms in Central and Eastern Europe. Budapest, 2002.

Carp, R. Strategii şi propuneri de reformă a administraţiei publice în perspectiva integrării europene. Revista de drept public. 2/2006. 
Carp, R., Gal, G.D., Mureşan, S., and Preda, R. În căutarea binelui comun. Cluj-Napoca: Eikon, 2008.

Claessens, S., and Djankov, S. Politicians and Firms in Seven Central and Eastern European Countries. Policy Research Working Paper Series 1954. Washington, D.C.: World Bank, 1998.

Cohen, J.M., and Peterson, S.B. Administrative Decentralization. Strategies for Developing Countries. West Hartford: Kumarian Press, 1999.

Craig, P. Subsidiarity: A Political and Legal Analysis. Journal of Common Market Studies. 2012, S1(50).

Crook, R., and Manor, J. Democratic Decentralization. Working Paper. Washington, D.C.: World Bank, 2002.

Dunn, J., and Wetzel, D. Fiscal Decentralization in Former Socialist Economies: Progress and Prospects. Washington, DC: World Bank, 2000.

Huque, A.S., and Zafarullah, H. (eds.). International Development Governance. New York: Taylor \& Francis, 2006.

Héraud, G. Le fédéralisme. Nice: Presses d'Europe, 1995.

Iancu, D.-C. (ed.). Local Reforms in Transition Democracies. Iaşi: Institutul European, 2013.

Illner, M. Territorial Decentralization: An Obstacle to Democratic Reform in Central and Eastern Europe. In Kimball, J. (ed.). The Transfer of Power: Decentralization in Central and Eastern Europe. Budapest: 1998.

Ionescu, C. Tratat de drept constituţional contemporan. Bucureşti: All Beck, 2003.

Iorgovan, A. Tratat de drept administrativ. Vol. I, 4th edition. Bucureşti: All Beck, 2005.
Klimovsky, D., and Radzik-Maruszak (eds.). Selected Aspects of Local and Regional Development. Nova Gorica: School of Advanced Social Studies in Nova Gorica, 2012.

Lajh, D. Slovenia. Nations in Transit 2011: Democratization from Central Europe to Eurasia [interactive]. <http://www. freedomhouse.org/sites/default/files/ inline_images/NIT-2011-Slovenia. pdf $>$.

Muraru, I., and Tănăsescu, E.S. (eds.). Constituţia României - comentariu pe articole. Bucureşti: CH Beck, 2008.

Millon-Delsol, C. L'Etat subsidiare. Paris: Presses Universitaires de France, 1992.

Nabaldian, J. Facilitating Community, Enabling Democracy: New Roles for Local Government Managers. Public Administration Review. 1999, 59(2).

Oxhorn, P., Selee, A.D., and Tulchin, J.S. (eds.). Decentralization, Democratic Governance, and Civil Society in Comparative Perspective: Africa, Asia, and Latin America. Washington: Woodrow Wilson Center Press, 2004.

Petak, Z. How to Measure Decentralization: The Case-Study from Central European Countries. Paper presented at the 'Building Social Capital and Self-Governing Capabilities in Diverse Societies' Workshop, Indiana University, Bloomington, June 2004.

Peters, G.B., and Pierre, J. (eds.). The Handbook of Public Administration. Washington: Sage, 2007.

Petrescu, R. N. Drept administrativ. Bucureşti: Hamangiu, 2009.

Popa, E. Autonomia locală în România. Bucureşti: All Beck, 1999. 
Profiroiu, M., and Profiroiu, A. Decentralization Process in Romania. Transylvanian Review of Administrative Sciences. 16 E/2006.

Santai, I. Drept administrativ şi ştiinţa administraţiei. Vol. I. Sibiu: Editura Universităţii Lucian Blaga, 1998.

Stanomir, I., Manolache, C., and Gheorghe, A. (eds.). Challenges of Transition. The-Post Communist Experience(s). Iaşi: Institutul European, 2014.

Tarangul, E. D. Tratat de drept administrativ român. Cernăuţi: Tipografia Glasul Bucovinei, 1944.
Treisman, D. Defining and Measuring Decentralization: A Global Perspective [interactive]. <http://www.sscnet.ucla. edu/polisci/faculty/treisman/Papers/ defin.pdf $>$.

Vedinaş, V. Drept administrativ. 4th edition. Bucureşti: Universul Juridic, 2009.

Vrabie, G., and Bălan, M. Organizarea politico-etatică a României. Iaşi: Institutul European, 2004.

\title{
DECENTRALIZACIJA RUMUNIJOJE: NEPAVYKUSI REFORMA KONSTITUCINIŲ RIBŲASPEKTU
}

\author{
Radu Carp \\ Bukarešto universitetas, Rumunija \\ Andra Karla Sienerth \\ Bukarešto universitetas, Rumunija
}

Anotacija. Straipsnyje lyginamuoju aspektu analizuojamas decentralizacijos procesas Rumunijoje bei aprašoma, kaip subsidiarumo principas buvo neišsamiai ar net neteisingai apibréžtas teisèkūroje, t. y. ìstatymuose priimtuose nuo 2004 iki 2006 metų, kas suponavo šiu teisès aktu igyvendinimo sunkumus. Straipsnyje analizuojamas 2013 metu decentralizacijos istatymo projektas, kuris $2014 \mathrm{~m}$. sausi Konstitucinio Teismo buvo pripažintas prieštaraujančiu Konstitucijai. Visi minimi teisès normu aktai yra nagrinejami iš Europos vietos savivaldos chartijos perspektyvos. Straipsnyje prieinama prie išvados, kad decentralizacijos procesas, kuris vyksta nuo Rumunijos Konstitucijos priemimo 1991 metais iki šiu dienu, yra ypač ydingas dèl savo laipsninio pobūdžio ir Europos vietos savivaldos chartijoje itvirtintu principu ignoravimo.

Reikšminiai žodžiai: Konstitucinis Teismas, decentralizacija, Europos vietos savivaldos chartija, viešasis administravimas, subsidiarumas. 


\title{
DECENTRALIZATION IN ROMANIA: A CONSTANT FAILED REFORM UNDER SCRUTINY FROM THE CONSTITUTIONAL LIMITS PERSPECTIVE
}

\author{
Radu Carp \\ University of Bucharest, Romania \\ Andra Karla Sienerth \\ University of Bucharest, Romania
}

Summary. Decentralization is mentioned in the Romanian Constitution of 1991 as a principle of public administration, without being defined. A framework-law was adopted only in 2004, after the revision of the Constitution, and it was entirely abrogated in 2006 by another framework-law. None of these laws have been fully applied, because they were made of general principles and of public policy statements. The article discusses the draft law on decentralization of 2013 that was declared unconstitutional by the Constitutional Court in January 2014. The Constitutional Court has developed in the Decision No. 1/2014 the argument that it has jurisdiction to decide not only on the unconstitutionality of the law, but also on the inconsistency between it and the legal framework. The Court relied on its previous jurisprudence and also on that of the ECHR and the CJEU and concluded that the draft law on decentralization "does not meet the constitutional requirements regarding the quality of the law". Consequently, the account of decentralization, since the introduction of this concept in the Constitution of 1991 up to now, is extremely unsatisfactory. The transfer of powers from central to local levels, the essence of decentralization, was limited and was done mainly in a descriptive form of the competences of local authorities by the successive laws concerning the local administration. A gradual approach was preferred, extremely cautious regarding the implementation of decentralization. The European Charter on Local Autonomy, albeit transposed in Romanian law since 1997, had no influence on the drafting of two framework laws from 2004 and 2006, a rule that even the law from 2013 makes no exception to. The article describes how the principle of subsidiarity has been incomplete or faulty defined by these frameworks-laws and, consequently, it was impossible to apply it. Other principles, such as proportionality or consultation of local authorities on decisions that directly affect them, were not introduced in the Romanian legislation. Until the failed attempt to conduct the transfer of competences in 2013, an approach merely describing the principles and stages of decentralization was the option. There is also the option to specify from the very beginning which are the institutions which competences are to be transferred to a lower level due to decentralization. This alternative was avoided, probably due to the finding of a weak administrative capacity that causes decentralization to result in institutions that cannot exercise their powers invested with. 
Keywords: administrative capacity, Constitutional Court, decentralization, European Charter of Local Self-Government, subsidiarity.

Radu Carp, Bukarešto universiteto Politikos mokslų fakulteto profesorius. Mokslinių tyrimų kryptys: lyginamoji konstitucinè teisè, Europos Sąjungos teisè, valstybinè religija.

Radu Carp, University of Bucharest, Faculty of Political Sciences, Professor. Research interests: comparative constitutional law, Law of European Union, state religion.

Andra Karla Sienerth, Bukarešto universiteto Politikos mokslų fakulteto doktorantè. Mokslinių tyrimų kryptys: regionalizacija ir viešojo administravimo reformos Rumunijoje.

Andra Karla Sienerth, University of Bucharest, Faculty of Political Sciences, PhD student. Research interests: regionalization and reforms of public administration in Romania. 